\section{Combining ability of potato parents for tuber appearance and tuber yield component traits}

\author{
Laerte Reis Terres ${ }^{1 *}$, Emerson Andrei Lenz ${ }^{1}$, Dediel Rocha ${ }^{1}$, Mu- \\ rilo Cerioli ${ }^{1}$ and Arione da Silva Pereira ${ }^{2}$
}

\begin{abstract}
The purpose of this study was to estimate the combining ability between two groups of potato parents in early generations of selection. Twelve potato families, derived from two groups of parents crossed in a $4 \times 3$ partial diallel design, were evaluated, in a randomized complete block design with three replications. Additive effects of genes were predominant for the traits tuber shape uniformity, tuber pointiness, tuber curvature, general tuber appearance, tuber size uniformity, tuber number, total tuber yield, and average tuber weight. With regard to general combining ability, for all tuber appearance traits, the foreign parents 'Pukara' and 'Asterix', and the national parent 'Eliza' contributed with complementary favorable alleles. For tuber yield component traits, the foreign parent 'Rioja' and the national parent 'Eliza' were outstanding. The specific combining ability indicated 'Pukara'/'Eliza' as the most promising cross for the development of superior genotypes for the traits general tuber appearance and tuber number.
\end{abstract}

Key words: Solanum tuberosum L., potato breeding, early generations, partial diallel.

\section{INTRODUCTION}

Potato is a highly heterozygous crop, in which the influence of additive gene action is known to be relevant for most agronomic traits. An advantage in potato breeding is that once identified, desirable traits can be multiplied vegetatively for a long time with no risk of segregation. To breed superior progenies, the selection of good parents and combinations of crosses are required. Information about the combining ability is fundamental for selection of suitable parents for hybridization (Kumar et al. 2008).

By the diallel method, important parameters can be estimated for parental selection and to obtain information about the genetic effects involved in the trait control. In the diallel analysis method proposed by Griffing (1956), the mean performance of each genotype is partitioned into the general combining ability (main effects) and specific combining ability (interactions). The general combining ability (GCA) indicates the mean behavior of a parent in a series of hybrid combinations and is associated with additive allele effects and additive epistatic actions, whereas the specific combining ability (SCA) indicates the deviations of hybrid performance from what would be expected, based on the GCA, and is associated with the effects of dominance and epistatic deviations, involving dominance (Cruz et al. 2012, Ramalho et al. 2012).
Crop Breeding and Applied Biotechnology 17: 99-106, 2017 Brazilian Society of Plant Breeding. Printed in Brazil http://dx.doi.org/10.1590/198470332017v17n2a16

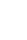

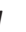




\section{LR Terres et al.}

For potato, several studies have used diallel analysis to estimate the combining abilities of parents (Barbosa and Pinto 1998, Galarreta et al. 2006, Silva et al. 2008). In an extensive review, Bradshaw and Mackay (1994) reported that GCA and SCA values have influenced, at different proportions, all economically relevant traits of potato. According to Neele et al. (1991), SCA tends to be more important than GCA in crosses with related parents since the number of different alleles may be more limited. Consequently, the variation in additive gene action will also be limited, so that non-additive gene action, e.g., epistasis, can lead to a relatively high variation among progenies. Therefore, the SCA effects are possibly more important than those of GCA. The objective of this study was to estimate the combining abilities between two groups of parents, foreign and Brazilian, of potato in early generations of selection.

\section{MATERIAL AND METHODS}

The experiments were carried out on an experimental field of Embrapa Temperate Climate, in Pelotas, RS (lat $31^{\circ} 40^{\prime} 18^{\prime \prime} \mathrm{S}$, long $52^{\circ} 26^{\prime} 15^{\prime \prime} \mathrm{W}$, alt $60 \mathrm{~m}$ asl). The soil was classified as sandy loam Typic Hapludox, and was fertilized in the planting furrows with $2,500 \mathrm{~kg} \mathrm{ha}^{-1}$ of NPK (5-30-10) fertilizer mixture. Twelve potato families were evaluated, derived from crosses between two groups of randomly selected potato parents, in a $4 \times 3$ partial diallel design, according to the experiment II model of Comstock and Robinson (1948). This model involves the evaluation of parents in two groups, which do or do not belong to a common set (Cruz et al. 2012). Group 1 of parents (foreign cultivars) consisted of 'Pukara' (Chile), 'Asterix' (Holland), 'Rioja' (Hungary), and 'Caesar' (UK); and group 2 (Brazilian cultivars/clones) contained 'Eliza', 'C1750-15-95', and 'C1730-7-94'. From these crossing combinations, 12 families were derived for evaluation.

Two experiments were carried out, each with a seedling generation and first field generation. In the fall growing seasons of 2010 and 2012, the seedling generations were grown in a greenhouse. The seeds were germinated in seed beds and the seedlings were transplanted into plastic bags containing two liters of commercial substrate to produce mini-tubers. The seedlings were arranged in a randomized complete block design, with three replications. Each plot consisted of a sample of 25 seedlings, taken at random at the time of transplantation, to represent the cross. The spacing between plants and between rows was $0.10 \mathrm{~m}$. The seedlings were maintained under these conditions until the time of harvest, after 80 days. The tubers were identified and transported to appropriate facilities for evaluation. After the evaluations, the tubers were stored in a cold chamber at $4{ }^{\circ} \mathrm{C}$.

In the fall growing season of 2011 and 2013, the first field generation was grown from each seedling generation. In the fall of 2011, the stored tubers of 2010 were used and in the fall growing season of 2013 the tubers of 2012. Each experimental unit consisted of three tubers of approximately type III size planted in the field (spaced $0.30 \times 0.80 \mathrm{~m}$, within and between rows, respectively), arranged in the same experimental design as in the previous growing season. Cultural and phytosanitary management were similar to those applied to commercial plantations in the region. The plots were harvested and the tubers evaluated shortly after.

The traits related to tuber appearance were assessed on a nine-point scale to classify tubers, assigning values between one (1) and nine (9), as follows: skin texture (1- rough, 9- smooth), eye depth (1- deep, 9- superficial), tuber eyebrow prominence (1- prominent, 9- superficial), tuber shape uniformity (1- rounded, 9- elongate), tuber shape uniformity (1- irregular, 9- regular), tuber pointiness (1- pointy, 9- not pointy), tuber curvature (1- curved, 9- not curved), tuber flattening (1- flat, 9- not flat), tuber size (1- small, 9- large), tuber size uniformity (1- variable, 9- uniform), and general tuber appearance (1- poor, 9- good). The general tuber appearance was considered good when the following criteria coincided: smooth skin, shallow eyes, superficial eyebrows, a regular, not pointed, not curved, and not flattened shape, and regular size. The following tuber yield traits were evaluated: number of tubers per plant, total tuber weight per plant (g plant $\left.{ }^{-1}\right)$, and mean tuber weight (g).'

The data were tested for normality of error distribution (Lilliefors) (Campos 1983). Subsequently, they were subjected to combined analysis of variance between the years of experiments and generations, and partial diallel analysis, to determine the general combining ability (GCA) and specific combining ability (SCA), using software Genes (Cruz 2013). Coefficients of determination $\left(R^{2}\right)$ were estimated based on the contribution in percentage of the sums of mean squares, in relation to the variation between families. 


\section{RESULTS AND DISCUSSION}

When testing data normality in the experiment of 2012 and 2013, the error distribution of eye depth and tuber flattening was not normal after transformation and, these traits were therefore excluded from the statistical analyses. The mean squares of the combined diallel analysis of the two experiments, as well as coefficients of determination $\left(R^{2}\right)$ of the general combining ability (GCA) and the specific combining ability (SCA) for all studied traits are shown in Table 1. The analysis of variance revealed significant differences $(p<0.05)$ among families for tuber skin texture, tuber shape and number of tubers. Moreover, the interaction between families and year was significant for these same traits and for tuber pointiness, tuber curvature, general tuber appearance, tuber size uniformity, and total tuber yield and mean tuber weight.

The contribution in percentage terms of the causes of variation due to the GCA of group 1 (GCA I), GCA of group 2 (GCA II) and SCA in relation to the sum of squares of crosses through the estimates of the coefficients of determination $\left(R^{2}\right)$ are also shown in Table 1 . Based on the relative contributions, the superiority of GCA $(I+I I)$ effects in relation to SCA was found for tuber shape uniformity, tuber pointiness, tuber curvature, general tuber appearance, tuber size uniformity, tuber number, and total tuber yield and mean tuber weight, indicating predominance of additive effects of the genes on the control of these traits. In other words, the mean value of the parents may be a good basis to predict

Table 1. Summary of the combined variance analysis with diallel effects partitioned for tuber appearance and tuber yield traits of potato tubers

\begin{tabular}{|c|c|c|c|c|c|c|c|c|c|c|c|c|c|}
\hline \multirow{2}{*}{$\begin{array}{l}\text { Source of } \\
\text { variation }\end{array}$} & \multirow[t]{2}{*}{ df } & \multicolumn{12}{|c|}{ Mean squares } \\
\hline & & $\mathrm{SKT}^{1}$ & TEP & TSH & UFO & TP & CUR & GTA & TSI & UTS & NUM & TY & ATW \\
\hline Year (Y) & 3 & $8.85^{*}$ & $43.97 *$ & $8.72 *$ & $12.14^{*}$ & $10.18^{*}$ & $9.21 *$ & $42.65^{*}$ & $20.24^{*}$ & $8.47^{*}$ & $1401.3^{*}$ & $87987 *$ & 19777* \\
\hline Family (F) & 11 & $3.04 *$ & 1.39 & $1.65^{*}$ & 0.68 & 1.18 & 0.86 & 0.26 & 0.92 & 0.78 & $11.87^{*}$ & 76858 & 64.01 \\
\hline $\mathrm{GCA} \mathrm{I}^{2}$ & 3 & 3.82 & 0.42 & $0.84 *$ & 0.58 & $1.71 *$ & 0.90 & 0.18 & $0.73^{*}$ & 1.76 & 24.50 & 75938 & 128.48 \\
\hline GCA II & 2 & 2.25 & $1.56^{*}$ & 0.07 & $1.16^{*}$ & 2.21 & 1.9 & 0.55 & 0.27 & 0.39 & 17.36 & 79501 & 5.75 \\
\hline SCA & 6 & 2.91 & 1.83 & $2.59 *$ & 0.57 & 0.58 & 0.5 & 0.19 & 1.23 & 0.42 & 3.50 & 9514 & 51.17 \\
\hline$G C A \| x Y$ & 6 & $0.84^{*}$ & 0.88 & 0.33 & 1.22 & 1.06 & $1.22 *$ & $0.36^{*}$ & 1.51 & $0.50 *$ & $4.01 *$ & 77368* & $60.41^{*}$ \\
\hline$S C A \times Y$ & 18 & $1.41^{*}$ & 0.53 & $0.93 *$ & 0.54 & 0.61 & 0.42 & $0.37^{*}$ & 0.79 & 0.56 & $3.14^{*}$ & 76885 & 32.34 \\
\hline Error & 88 & 0.35 & 0.58 & 0.31 & 0.58 & 0.49 & 0.50 & 0.11 & 0.52 & 0.49 & 0.91 & 43.95 & 27.11 \\
\hline $\mathrm{R}^{2} \operatorname{cgc} \mathrm{I}(\%)^{3}$ & & 34.27 & 8.24 & 13.88 & 23.26 & 39.52 & 28.54 & 18.89 & 21.64 & 61.53 & 56.29 & 53.94 & 54.33 \\
\hline $\mathrm{R}^{2} \operatorname{cgc} \|(\%)$ & & 13.45 & 20.40 & 0.51 & 31.01 & 34.05 & 40.17 & 38.46 & 8.00 & 0.92 & 26.59 & 38.81 & 2.07 \\
\hline
\end{tabular}

Table 2. General combining ability of potato parents for tuber appearance traits evaluated in four experiments

\begin{tabular}{|c|c|c|c|c|c|}
\hline \multirow{2}{*}{ Parents } & \multicolumn{5}{|c|}{ Traits } \\
\hline & TEP $^{1}$ & TSH & UFO & TP & TSI \\
\hline \multicolumn{6}{|l|}{ Group 1} \\
\hline Pukara & -0.15 & $0.05^{*}$ & -0.17 & $0.32 *$ & $-0.07^{*}$ \\
\hline Asterix & 0.02 & $0.19^{*}$ & 0.10 & $-0.08^{*}$ & $-0.16^{*}$ \\
\hline Rioja & 0.01 & $-0.08^{*}$ & 0.09 & $-0.10^{*}$ & $0.09 *$ \\
\hline Caesar & 0.13 & $-0.16^{*}$ & -0.02 & $-0.14^{*}$ & $0.14^{*}$ \\
\hline \multicolumn{6}{|l|}{ Group 2} \\
\hline C1730-7-94 & $0.16^{*}$ & 0.03 & $0.15^{*}$ & 0.06 & 0.08 \\
\hline C1750-15-95 & $0.03^{*}$ & 0.01 & $0.02 *$ & 0.17 & -0.07 \\
\hline Eliza & $-0.19 *$ & -0.04 & $-0.16^{*}$ & -0.23 & 0.01 \\
\hline
\end{tabular}

${ }^{1}$ See code in Table 1 


\section{LR Terres et al.}

the performance of progenies (Bradshaw and Mackay 1994).

With regard to tuber shape, tuber pointiness and tuber size, a greater effect of SCA was observed. The relative importance of GCA and SCA depends on the genetic constitution of the parents involved in the crosses, the evaluated trait, the experimental design and the environmental conditions (Manivel et al. 2010). In varying proportions, the values of GCA and SCA estimated by several authors, influence all economically important traits of potato (Bradshaw and Mackay 1994).

Furthermore, for tuber skin texture, tuber shape, tuber size, tuber size uniformity, tuber number, and tuber weight and mean tuber weight, the relative contribution of the GCA of the Brazilian parents (GCA II) was lower than that of the foreign (parents I), indicating that for these traits, these cultivars had greater influence on the performance of hybrids obtained in crosses with the Brazilian cultivars (Table 1). In contrast, for tuber eyebrow prominence, tuber shape uniformity, tuber curvature, and general tuber appearance, the relative contribution of the national cultivars was higher than that of the foreign.

The higher GCA values found in this study for yield-related traits agree with reports of some authors (Ortiz and Golmirzaie 2004, Silva et al. 2013), but differ from others (Barbosa and Pinto 1998, Gopal 1998, Galarreta et al. 2006). The second group reported the predominance of significance of SCA over GCA. The predominance of SCA for tuber number and a higher GCA for average tuber weight were reported by Tai and De Jong (1991), who concluded that tuber number results from continuous directional selection, while the average tuber weight results from stabilization in selection. A similar significance of SCA and GCA for tuber yield traits was also observed by Silva et al. (2009).

For tuber eyebrow prominence, only parents of group 2 differed, and the highest positive value was found for 'C1730-7-94', contributing to a lower eyebrow prominence, while 'Eliza' contributed to a higher eyebrow prominence.

With regard to the trait tuber shape, the differences between the estimates of group 1 were significant. The highest positive value was found for 'Asterix', favoring the generation of families with more elongated tubers, as also stated by Silva et al. (2013) for this cultivar, evidencing additive gene effects, in view of the elongated shape of tubers of this cultivar. On the other hand, 'Caesar' presented the highest negative value, that is, more rounded tubers. According to Figueiredo et al. (2015), selection for tuber shape among families may be applied in the seedling generation.

In relation to the uniformity of tuber shape, 'C1730-7-94' was the best parent of group 2, contributing to tubers with a more regular shape, while 'Eliza' contributed to more irregular tubers, with a higher negative value.

For the trait tuber pointiness, for group 1, 'Pukara' was the best parent, while 'Asterix', 'Rioja' and 'Caesar' had negative values, contributing to the generation of more pointed tuber families.

For the trait tuber size, 'Caesar' stood out by contributing larger tubers, while 'Asterix' generated smaller tubers when crossed with genotypes of group 2. In a study of combining ability, Silva et al. (2013) verified that cultivar Asterix contributed to a greater tuber number, but also to a smaller tuber size.

The GCA estimates of the four experiments, corresponding to the seedling generations of 2010 and 2012 and their respective field generations of 2011 and 2013, are listed in Table 3. For the trait skin texture, the estimates were significant for both groups of parents in the seedling generation of 2010, for group 2 in the field generation of 2011, and for group 1 in the seedling generation of 2012. In both seedling generations, 'Pukara' presented highest positive values, contributing to a smoother tuber skin texture, opposite to cultivar Rioja, which is not recommended for crosses targeting populations with smooth skin. Of the parents of group 2, 'Eliza' contributed most to smooth skin texture in the 2010 seedling generation and in the field generation of 2011, whereas 'C1730-7-94' and 'C1750-15-95' had negative values, contributing to a rougher texture.

For the trait tuber curvature, 'C1750-15-95' of group 2 contributed to families with less curved tubers in the seedling generation of 2010. In this generation, 'C1730-7-94' had the highest negative estimate, contributing to families with a higher incidence of curved tubers. For parents of group 1, in the field generation of 2013 and the seedling generation of 2012, 'Puraka' had a higher and positive value than the others, which had no consistent behavior in both generations.

With regard to the trait general tuber appearance, which is fundamental for the acceptance of a cultivar on the 
fresh market (Silva et al. 2008), the GCA estimates for parents of group 1 were significant in both seedling generations, in which the values of the parents 'Pukara' and 'Asterix' were positive in both generations. Thus, these parents would be indicated for crosses to breed families with a better general tuber appearance. In 2010, 'Caesar' had a positive value and the highest negative value in 2012 for this trait, i.e., this parent was not stable. The opposite was observed for 'Rioja', which had negative estimates in the first year and positive in 2012. For parents of group 2, the values for 'Eliza' were positive in the seedling generation of 2010 and in the field generation of 2011, and was therefore identified as the most suitable parent to obtain families with good general tuber appearance.

For the tuber size uniformity, the parents 'Pukara' and 'Asterix' had the highest GCA in the seedling generation of 2012 , contributing to plant families with tubers of a more regular size. For parents of group 2, in the field generation of 2013, the GCA estimate for 'C1750-15-95' was the highest for this trait.

In the trait set of tuber appearance components, the parents 'Pukara' and 'Asterix' of group 1 had a higher GCA, since they had higher positive values, contributing with additive gene effects. For parents of group 2, 'Eliza' stood out with more positive values for tuber appearance traits. For the set of tuber yield component traits, 'Rioja' of group 1 performed best, since the GCA values were highest, similar to those reported by Silva et al. (2009).

Table 3. General combining ability of potato parents for traits related to general tuber appearance and tuber yield, evaluated in early generations of selection

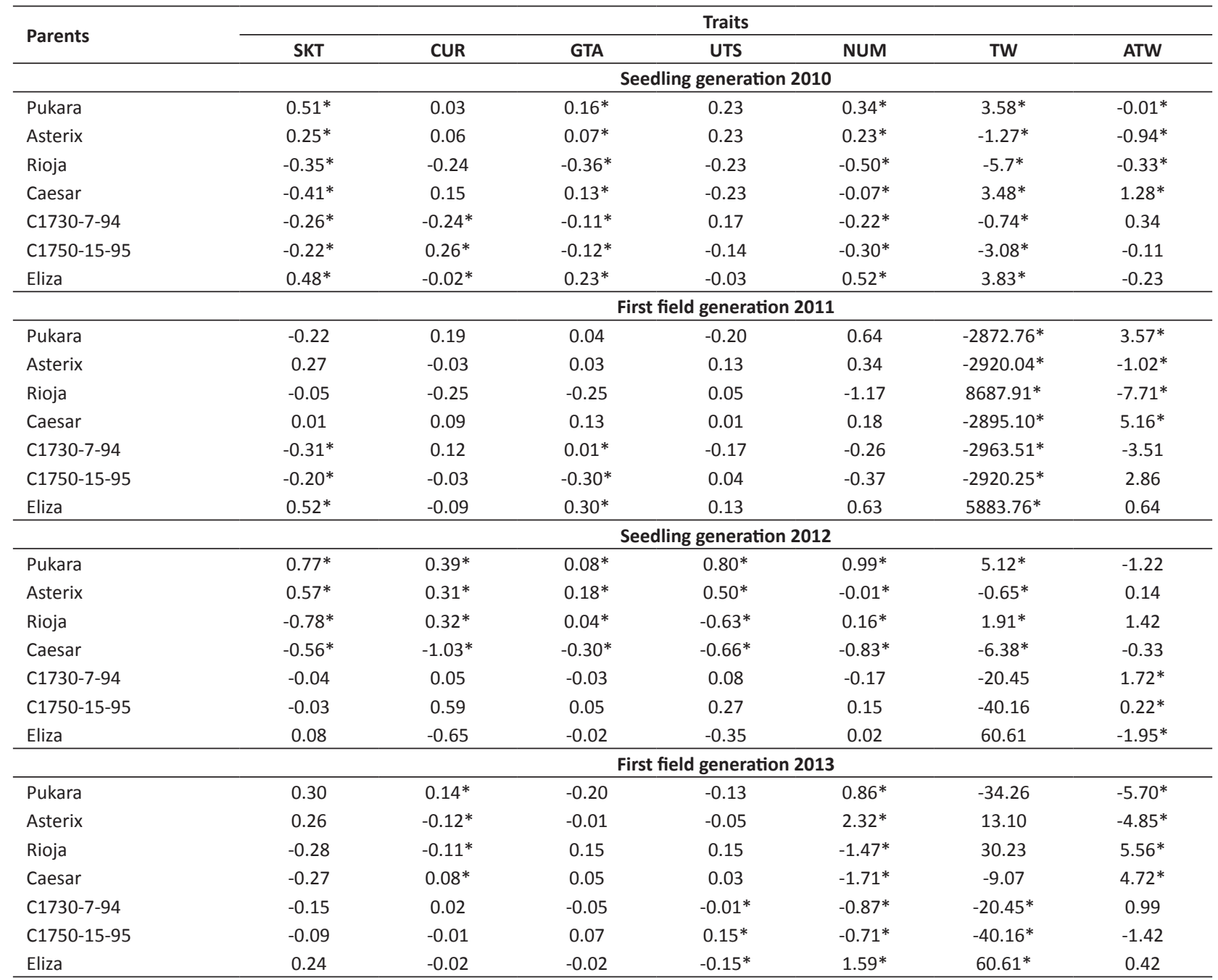

${ }^{1}$ See code in Table 1 
Table 4. Specific combining ability of potato parents for the traits tuber appearance and tuber yield, evaluated in early generations of selection

\begin{tabular}{|c|c|c|c|c|c|c|}
\hline \multirow{2}{*}{ Crosses } & \multirow{2}{*}{ Generations } & \multicolumn{5}{|c|}{ Traits } \\
\hline & & SKT & TEP & TSH & GTA & NUM \\
\hline Pukara/C1730-7-94 & \multirow{9}{*}{ Seedling 2010} & $-1.09 *$ & $0.38^{*}$ & $-0.64 *$ & -0.07 & $-0.53^{*}$ \\
\hline Pukara/Eliza & & $0.62^{*}$ & $0.14^{*}$ & $0.08^{*}$ & 0.18 & $0.40^{*}$ \\
\hline Asterix/C1730-7-94 & & $0.98^{*}$ & $-0.51^{*}$ & $0.35^{*}$ & 0.39 & $0.20^{*}$ \\
\hline Asterix/C1750-15-95 & & -0.80 & $0.39 *$ & $-0.51^{*}$ & -0.09 & $-0.24 *$ \\
\hline Rioja/C1730-7-94 & & $-0.45^{*}$ & $-0.01 *$ & $-0.25^{*}$ & -0.33 & $0.03 *$ \\
\hline Rioja/C1750-15-95 & & $0.22 *$ & $-0.19 *$ & $-0.07 *$ & 0.13 & $0.16^{*}$ \\
\hline Rioja/Eliza & & $0.23 *$ & $0.20^{*}$ & $0.32^{*}$ & 0.20 & $-0.19 *$ \\
\hline CaesarC1730-7-94 & & $0.56^{*}$ & $0.14^{*}$ & $0.54^{*}$ & 0.02 & $0.30^{*}$ \\
\hline Caesar/C1750-15-95 & & $0.12^{*}$ & $0.32 *$ & $0.02 *$ & 0.06 & $-0.04 *$ \\
\hline Asterix/C1730-7-94 & \multirow{9}{*}{$\begin{array}{l}1^{\text {st }} \text { field genera- } \\
\text { tion } 2011\end{array}$} & 0.70 & 0.09 & $-0.36 *$ & 0.22 & 0.21 \\
\hline Asterix/C1750-15-95 & & -0.21 & -0.21 & $-0.31 *$ & -0.28 & 0.50 \\
\hline Asterix/Eliza & & -0.48 & 0.13 & $0.68^{*}$ & 0.06 & -0.70 \\
\hline Rioja/C1730-7-94 & & -0.65 & 0.16 & $-0.21^{*}$ & -0.04 & -0.98 \\
\hline Rioja/C1750-15-95 & & 0.30 & -0.05 & $0.24 *$ & 0.24 & 0.48 \\
\hline Rioja/Eliza & & 0.36 & -0.11 & $-0.03 *$ & -0.20 & 0.50 \\
\hline CaesarC1730-7-94 & & 0.43 & -0.34 & $0.73^{*}$ & -0.14 & 1.14 \\
\hline Caesar/C1750-15-95 & & -0.20 & 0.55 & $0.11^{*}$ & 0.20 & -0.43 \\
\hline Caesar/Eliza & & -0.22 & -0.20 & $-0.84 *$ & -0.05 & -0.71 \\
\hline Pukara/C1730-7-94 & \multirow{5}{*}{ Seedling 2012} & $-0.01 *$ & 0.86 & $-0.16^{*}$ & $0.18^{*}$ & $-0.66^{*}$ \\
\hline Rioja/Eliza & & $0.18^{*}$ & 0.39 & $1.20^{*}$ & $0.31 *$ & $-0.02 *$ \\
\hline CaesarC1730-7-94 & & $1.59 *$ & 0.44 & $1.21^{*}$ & $0.44^{*}$ & $0.29 *$ \\
\hline Caesar/C1750-15-95 & & $-0.41^{*}$ & 0.31 & $0.17^{*}$ & $0.01^{*}$ & $0.47^{*}$ \\
\hline Caesar/Eliza & & $-1.18^{*}$ & -0.75 & $-1.38^{*}$ & $-0.44 *$ & $-0.76^{*}$ \\
\hline Pukara/C1730-7-94 & \multirow{12}{*}{$\begin{array}{l}1^{\text {st }} \text { field genera- } \\
\text { tion } \\
2013\end{array}$} & $-0.62^{*}$ & $0.30^{*}$ & $-0.16^{*}$ & $-0.32 *$ & $0.33^{*}$ \\
\hline Pukara/C1750-15-95 & & $0.26^{*}$ & $-0.50 *$ & $0.20^{*}$ & $0.06 *$ & $-0.69 *$ \\
\hline Pukara/Eliza & & $0.35^{*}$ & $0.20 *$ & $-0.04 *$ & $0.25^{*}$ & $0.36^{*}$ \\
\hline Asterix/C1730-7-94 & & $0.38^{*}$ & $0.18^{*}$ & $0.06^{*}$ & $0.29 *$ & $-1.90 *$ \\
\hline Asterix/C1750-15-95 & & $-0.13 *$ & $0.40^{*}$ & $0.12^{*}$ & $-0.02 *$ & $-0.39 *$ \\
\hline Asterix/Eliza & & $-0.24 *$ & $-0.58^{*}$ & $-0.18^{*}$ & $-0.26 *$ & $2.29 *$ \\
\hline Rioja/C1730-7-94 & & $0.37^{*}$ & $-0.32 *$ & $-0.18 *$ & $0.42 *$ & $1.26^{*}$ \\
\hline Rioja/C1750-15-95 & & $-0.31^{*}$ & $-0.09 *$ & $0.22 *$ & $-0.39 *$ & $0.93^{*}$ \\
\hline Rioja/Eliza & & $-0.05^{*}$ & $0.41 *$ & $-0.03 *$ & $-0.03 *$ & $-2.20 *$ \\
\hline CaesarC1730-7-94 & & $-0.13^{*}$ & $-0.16^{*}$ & $0.29 *$ & $-0.39 *$ & $0.31 *$ \\
\hline Caesar/C1750-15-95 & & $0.18^{*}$ & $0.19 *$ & $-0.54 *$ & $0.35^{*}$ & $0.15^{*}$ \\
\hline Caesar/Eliza & & $-0.05^{*}$ & $-0.02 *$ & $0.25^{*}$ & $0.04 *$ & $-0.46^{*}$ \\
\hline
\end{tabular}

${ }^{1}$ See code in Table 1 
For the trait skin texture, the most stable results of all four evaluations, the cross 'Caesar'/'C1730-7-94' showed the highest positive values, contributing to a smoother skin. On the other hand, cross 'Pukara'/'C1730-7-94' can favor the production of a population with tubers of rough skin.

For the trait tuber shape, in each year, the SCA estimates of cross 'Caesar'/'C1730-7-94' were positive and highest, favoring the formation of more elongated tubers. On the other hand, cross 'Caesar/Eliza' was the most favorable for rounded tubers.

For the trait general tuber appearance, SCA estimates were significant in the seedling generation of 2012 and field generation of 2013. However, the crosses were not stable, and the values differed in these two generations. In the seedling generation, the cross 'Caesar'/'C1730-7-94' performed particularly well, contributing to a better general tuber appearance, while the cross 'Caesar/Eliza' induced a worse appearance. In the field generation of 2013, the best cross was 'Rioja'/'C1750-15-95', inducing a better tuber appearance, while the crosses 'Rioja'/'C1730-7-94' and 'Caesar'/'C1730-7-94' had the highest negative estimates.

With regard to the yield component traits, the SCA estimates were only significant for tuber number, analogously to the GCA estimates for this trait. Other authors also verified the significance of both combining abilities for tuber number (Barbosa and Pinto 1998, Silva et al. 2013), but found significant estimates for the other yield-related traits, such as total tuber yield and average tuber weight. The SCA estimates of the crosses 'Pukara'/'Eliza' and 'Caesar'/'C1730-7-94' were positive in all generations, contributing to a higher tuber number. The cross 'Pukara'/'Eliza' can be recommended to target a higher tuber number, since the GCA estimates of both parents were positive.

It can be concluded that tuber shape uniformity, tuber pointiness, tuber curvature, general tuber appearance, tuber size uniformity, tuber number, total tuber yield and average tuber weight were predominantly influenced by additive gene effects.

In the set of tuber appearance traits, the foreign parents 'Pukara' and 'Asterix', and the Brazilian parent 'Eliza' contributed to the generation of families with complementary favorable alleles. For the tuber yield component traits, the foreign parent 'Rioja' and the national 'Eliza' were noteworthy.

For the specific combining ability, 'Pukara'/'Eliza' is the most promising cross for the development of superior genotypes for general tuber appearance and tuber number traits.

\section{ACKNOWLEDGEMENTS}

The authors are indebted to the Coordination for the Improvement of Higher Education Personnel (CAPES) and National Counsel of Technological and Scientific Development (CNPq) for funding and scholarships for this research project.

\section{REFERENCES}

Barbosa MHP and Pinto CAB (1998) Análise dialélica parcial entre cultivares de batata nacionais e introduzidas. Pesquisa Agropecuária Brasileira 33: 307-320.

Bradshaw JE and Mackay GR (1994) Breeding strategies for clonally propagated potatoes. In Bradshaw JE and Mackay GR (eds) Potato genetics. CAB International, Wallingford, p. 467-497.

Campos H (1983) Estatística experimental não-paramétrica. FEALQ, Piracicaba, 349p.

Comstock RE and Robinson HF (1948) The components of genetic variance in populations. Biometrics 4: 254-266.

Cruz CD (2013) GENES - a software package for analysis in experimental statistics and quantitative genetics. Acta Scientiarum 35: 271-276.

Cruz CD, Regazzi AJ and Carneiro PC (2012) Modelos biométricos aplicados ao melhoramento genético. V. 1, edn. 4, Editora UFV, Viçosa, 514p.

Figueiredo ICR, Pinto CABP, Ribeiro GHMR, Lino LO, Lyra DH and Moreira CM (2015) Efficiency of selection in early generations of potato families of a view toward heat tolerance. Crop Breeding and Applied Biotechnology 15: 210-217.

Galarreta JIR, Ezpeleta B, Pascualena J and Ritter E (2006) Combining ability and correlations for yield components in early generations of potato breeding. Plant Breeding 125: 183-186.

Gopal J (1998) Identification of superior parents and crosses in potato breeding programmes. Theoretical and Applied Genetics 96: 287293.

Griffing B (1956) Concept of general and specific combining ability in relation to diallel crossing systems. Australian Journal of Biological Sciences 9: 463-493. 


\section{$L R$ Terres et al.}

Kumar R, Kang GS and Pandey SK (2008) Estimation of genetic parameters and combining ability for characters related to potato propagation by true potato seed. Potato Journal 35: 12-18.

Manivel P, Pandel SK, Singh SV and Kumar D (2010) Heterosis and combining ability for tuber dry matter and yield in potato (Solanum tuberosum L.) over two clonal generations under short-day sub-tropic conditions. Electronic Journal of Plant Breeding 1: 287-296.

Neele AEF, Nab HJ and Louwes KM (1991) Identification of superior parents in a potato breeding programme. Theoretical and Applied Genetics 82: 185-197.

Ortiz R and Golmirzaie AM (2004) Combining ability analysis and correlation between breeding values in true potato seed. Plant Breeding 123: 564-567.

Ramalho MAP, Santos JB, Abreu AFB and Nunes JAR (2012) Aplicações da genética quantitativa no melhoramento de plantas autógamas. Editora UFLA, Lavras, 522p.

Silva GO, Ney VG, Terres LR, Pereira AS and Suinaga FA (2013) Capacidade de combinação de genitores de batata para caracteres de aparência e rendimento de tubérculos. Revista Ceres 60: 489-497.

Silva GO, Pereira AS, Souza VQ, Carvalho FIF and Fritsche Neto R (2009) Estimativa de capacidades de combinação em gerações iniciais de seleção de batata. Horticultura Brasileira 27: 275-279.

Silva GO, Pereira AS, Souza VQ, Carvalho FIF and Vieira EA (2008) Capacidade de combinação multivariada para caracteres de tubérculo em gerações iniciais de seleção de batata. Ciência Rural 38: 321-325.

Tai GCC and De Jong H (1991) Evaluation of potato hybrids obtained from tetraploid-diploid crosses. Plant Breeding 107: 183-189. 